\title{
PENINGKATAN KETRAMPILAN MEDIA KOMUNIKASI DAN PERLUASAN KERJASAMA DALAM PENCEGAHAN NARKOBA OLEH POLDA DIY DAN BNNP YOGYAKARTA
}

\author{
Basuki $^{1}$ dan Panji Dwi Ashrianto ${ }^{2}$ \\ Program Studi Ilmu Komunikasi \\ Fakultas Ilmu Sosial dan Ilmu Politik \\ Universitas Pembangunan Nasional Veteran Yogyakarta \\ Jalan Babarsari No. 2 Tambakbayan Yogyakarta \\ Email: 'basuki_upnjogja@yahoo.com; ${ }^{2}$ Panji_adver@yahoo.co.id
}

\begin{abstract}
The consumption of narcotics, drugs and its kind in Indonesia is worrying. Indonesia's condition already considered as 'drugs emergency'. There is no area that free from the abuse of drugs and its kind. Yogyakarta considered as number 5 in Indonesia in term of this case. This rank categorized Yogyakarta into 'drug emergency'category. Society must be protected. The institution that expected to prevent and overcome this case is Indonesian National Police and National Anti Narcotics Agency. Reinforcement and support are needed for these institutions. The principal of preventing the usage or the drugs abuse is better than rehabilitating addiction. These institutions do not yet optimize the utilization and proficiency of Technology of communication. Therefore, this enhancement and improvement to the technology of communication skills of the officers from institutions National Anti Narcotics Agency (BNNP) and Indonesian National Police of Yogyakarta province (Polda DIY) is needed. The result of this IbM is the improvement of: first, the participant capable in mapping the audience. Second, participants able to create concept and applied it into scenario. Third, participants are able to take picture. Fort, participants are able to produce the audiovisual production. Fifth, participants could edit the picture. Sixth, the participants are able to broaden the networking with various communication media (including able to manage the social media). Sevenths, the participants are able to make press release. The output of this IbM is short movies, MoU of collaboration between BNNP and POLDA DIY with various media, newspaper and electronic in Yogyakarta.
\end{abstract}

Keyword : Skills, Communication Media, Collaboration networks

\begin{abstract}
Abstrak
Tingkat konsumsi narkoba dan sejensnya di Indonesia sudah sangat mengkhawatirkan. Kondisi Indonesia sudah dikategorikan sebagai "darurat narkoba". Tidak ada wilayah di Indonesia yang terbebas dari jeratan narkoba. Daerah Istimewa Yogyakarta masuk urutan kelima. Peringkat ini sudah mengkategorikan Yogyakarta dalam kategori "darurat narkoba". Masyarakat harus dilindungi. Lembaga yang menjadi ujung tombak dari pencegahan dan penanggulangan dampak adalah Polri dan BNN. Penguatan dan dukungan terhadap dua lembaga ini perlu dilakukan. Prinsip mencegah penggunaan narkoba lebih baik dari rehabilitasi pecandu. Penggunaan dan penguasaan teknologi komunikasi belum banyak dipakai untuk sosialisasi pada
\end{abstract}


masyarakat oleh kedua lembaga tersebut. Untuk itu perlu peningkatan keterampilan teknologi komunikasi oleh personil BNNP Yogyakarta dan Polda DIY. Hasil dari IbM ini adalah peningkatan: pertama, peserta mampu dalam memetakan audience. Kedua, peserta mampu membuat konsep dan menuangkannya dalam skenario. Ketiga, peserta mampu melakukan pengambila gambar. Keempat, peserta mampu melaksanakan produksi audio visual. Kelima, peserta mampu editing gambar. Keenam, peserta mampu memperluas jaringan kerjasama dengan berbagai media komunikasi (termasuk mampu mengelola media sosial). Ketujuh, peserta mampu membuat press release. Adapun bentuk luaran dari IbM ini adalah film pendek, Iklan Layanan Masyarakat (ILM), portal web dan media social, MoU kerjasama antara BNNP DIY ataupun Polda DIY dengan media cetak dan elektronik di Yogyakarta.

\section{Kata kunci : Ketrampilan, Media Komunikasi, Jaringan Kerjasama}

\section{PENDAHULUAN}

Tingkat konsumsi narkoba dan sejenisnya di Indonesia sudah sangat mengkhawatirkan. Presiden Jokowi saat memberikan kuliah umum di Universitas Gadjah Mada pada 9 Desember 2014 menyatakan bahwa Indonesia sudah masuk kondisi "Darurat Narkoba". Lebih lanjut Presiden mengungkapkan bahwa terdapat 4,5 juta orang yang harus direhabilitasi dan 1.2 juta orang yang kondisinya sudah tidak bisa direhabilitasi karena sudah terlalu parah. Data menunjukkan bahwa sebanyak 4050 orang meninggal setiap harinya karena narkoba. Untuk itu Presiden berketetapan untuk menolak grasi yang diajukan oleh 64 terpidana mati pengedar narkoba (antaranews.com/berita/468342/pre). Pada pembukaan rakornas pemberantasan narkoba di Gedung Bidakara 4 Pebruari 2015, Presiden meminta lembaga penegak hukum, komunitas masyarakat untuk berperan aktif dan tidak menganggap remeh peredaran dan penyalahgunaan narkoba. (nasional.kompas. $\mathrm{com} / \mathrm{read} / 2015 / 02$ ).

Para bandar narkoba terus mengembangkan berbagai varian baru narkoba. Setiap tahun ada 50 jenis narkoba baru, muncul di Indonesia. Seperti dikatakan Dadun (peneliti dari Pusat Kesehatan Universitas Indonesia) (radarpena.com 6 Desember 2014) bahwa "tak heran bila sekitar 50 jenis narkoba baru bermunculan di Indonesia. Hal ini dikarenakan jumlah usia produktif sangat tinggi. Selain kematian, Indonesia juga dirugikan secara ekonomi yang mencapai 48 trilliun per tahun.

Kerugian yang paling mendasar adalah rusaknya generasi muda. Jika generasi muda lemah bahkan rusak maka tinggal menunggu waktu akan kehancuran sebagai sebuah bangsa. Narkoba tidak hanya merusak fisik tetapi yang lebih parah justru merusak mental. Merehabilitasi korban narkoba jauh lebih sulit daripada merehabilitasi penyakit fisik.

Daerah Istimewa Yogyakarta menduduki peringkat kelima dalam tingkat konsumsi narkoba. Gubernur menyatakan hal itu pada peringatan Hari Anti Narkoba Internasional pada 26 Juni 2014. Jumlah pengguna narkoba di DIY setiap tahunnya terus meningkat. Data menunjukkan bahwa angka kenaikkan sebesar $0.12 \%$. Dengan demikian pada tahun 2014 jumlah pengguna narkoba diperkirakan 97.432 dan tahun 2015 diprediksi mencapai 109.675 (3.37 \%) dari jumlah penduduk DIY. (www.rri.co.id). Ketua umum Gerakan Nasional Anti Narkoba (GRANAT) DIY yaitu Ryan H Nugroho menyebutkan bahwa Yogyakarta sudah masuk "kondisi darurat narkoba". Salah satu penyumbangnya adalah meningkatnya tingkat perekonomian masyarakat. Salah satu indikatornya adalah perubahan pengguna narkoba ke jenis yang lebih mahal. Kalau dulu cukup ganja sekarang sudah heroin (suaramerdeka.com, 2 Februari 2015). Satu hal yang juga perlu mendapat 
perhatian adalah DIY terkenal dengan kota pelajar. Banyak pelajar dari luar daerah yang datang ke Yogyakarta untuk menuntut ilmu. Mereka menjadi sasaran empuk para bandar narkoba

Salah satu kunci upaya pencegahan adalah membentengi setiap warga dan anak Indonesia untuk tidak mengkonsumsi narkoba. Upaya pencegahan jauh lebih baik daripada pengobatan (rehabilitasi). Korban narkoba tidak hanya sakit fisik tetapi juga mental. Aspek kerusakan mental ini jauh lebih sulit untuk direhabilitasi. Sosialisasi pada masyarakat akan bahaya narkoba harus terus dintensifkan.

Leading Sector (lembaga penting) dalam penanggulangan narkoba di DIY adalah BNNP DIY dan Direktorat Reserse Narkoba POLDA DIY. Tugas BNNP DIY mulai dari pencegahan, pemberdayaan masyarakat, rehabilitasi pengguna, upaya pengungkapan jaringan pengedar. Sementara tugas Ditresnarkoba POLDA DIY adalah penyidikan dan penyelidikan kasus narkoba, dan melaksanakan penyuluhan untuk meningkatkan partisipasi masyarakat. Dua lembaga ini punya salah satu fungsi yang sama yaitu pencegahan melalui pemberdayaan masyarakat atas bahaya narkoba.

Untuk itu dua lembaga ini seharusnya juga secara massif pula memberikan informasi kekinian tentang narkoba kepada masyarakat. Pendekatan komunikasi interpesonal (face to face) memang efektif, tetapi daya jangkau sangat terbatas. Saat ini perkembangan teknologi informasi dan teknologi komunikasi sudah begitu pesat. BNNP DIY dan Ditresnarkoba POLDA DIY sudah seharusnya menggunakan berbagai media (media massa, ataupun media online) untuk memberdayakan masyarakat terhadap ancaman narkoba. Peningkatan penguasaan teknologi informasi dan teknologi komunikasi personil BNNP DIY dan Ditresnarkoba Polda DIY perlu dioptimalkan. Dengan demikian mereka mampu membuat pesan-pesan yang kreatif untuk ditayangkan melaui berbagai media.

\section{METODE PELAKSANAAN}

Mitra dari kegitan IbM ini adalah BNNP DIY dan Ditresnarkoba POLDA DIY. Persolan yang dihadapi oleh mitra adalah : 1) Peredaran narkoba yang semakin massif. Berbagai bentuk sanksi hukuman (bahkan hukuman mati) yang dijatuhkan pada para pengedar narkoba tidak membuat jera, bahkan mereka mampu mengendalikan bisnis dari balik jeruji. Jaringan bisnis mereka justru semakin luas dan sulit dilacak karena menggunakan rantai terputus. Disamping itu mereka juga terus mengembangkan berbagai varian narkoba. Perkembangan terakhir mereka mengemas dalam berbagai bentuk makanan yang menarik selera seperti kue dan kembang gula. 2) Upaya pencegahan tidak inovatif dan kurang agresif. Sosialisasi pada masyarakat masih menggunakan metode face to face sehingga tidak menjangkau khalayak secara massal. 3) Tersedianya teknologi komunikasi yang begitu canggih tidak dimanfaatkan secara maksimal oleh BNNP DIY dan Polda DIY dalam upaya sosialisasi pada masyarakat. Disamping itu kemampuan mereka dalam menggunakan teknologi tersebut masih rendah.

Kegiatan IbM ini berusaha membantu mitra untuk dapat memaksimalkan proses kegiatan penyuluhan masyarakat terhadap pencegahan peredaran narkoba, dengan menggunakan berbagai media. Berdasarkan identifikasi permasalahan, maka metode kegiatan yang akan dilakukan untuk menjawab masalah mitra adalah :

1. Workshop pembuatan materi penyuluhan dan sosialisasi berupa film pendek dan iklan layanan masyarakat. Materi yang diberikan adalah pembuatan konsep, teknik penulisan naskah, teknik pengambilan gambar, teknik editing, teknik backsound \& jingle.

2. Workshop pengelolaan media streaming dan pembuatan naskah press realese.

3. Pendampingan pembuatan film pendek, film iklan layanan masyarakat (audio, audio visual), press release, pengelolaan media sosial, pendampingan perluasan jaringan kerja sama. 
Kegiatan workshop dilakukan selama 3 hari (25-27 Agustus 2016) dengan pemberian materi dan praktek. Workshop diadakan di Laboratorium Public Relation UPN "Veteran" Yogyakarta. BNNP DIY mengirimkan 7 peserta dan Ditresnarkoba POLDA DIY mengikutkan 6 peserta. Adapun nama-nama peserta sebagai berikut :

1. Peserta Dari Ditresnarkoba Polda DIY
a. AKP. Sapto Sudaryanto, SH
b. Bripka. Dedi Hermawan, Amd
c. Bripka. Fuad Hasyim
d. Bripka. Eko Prasetyo S.
e. Bripka. Sigit Suharyadi
f. Brigadir Memet Subagyo

2. Peserta Dari BNNP DIY
a. Elmi Puji A, S.ST.FT
b. Hindun Kurnia N, S.KM
c. Herlina Rahmawati, SIP
d. Lisa Sunaryo Putri, S.Psi
e. Santy Dwi Kristina, S.K
f. Adhika Pertiwi, S.Sos
g. Floriberta Y.I.A.H, S.Farm, Apt

Kegiatan selanjutnya adalah pendampingan lapangan untuk menghasilkan
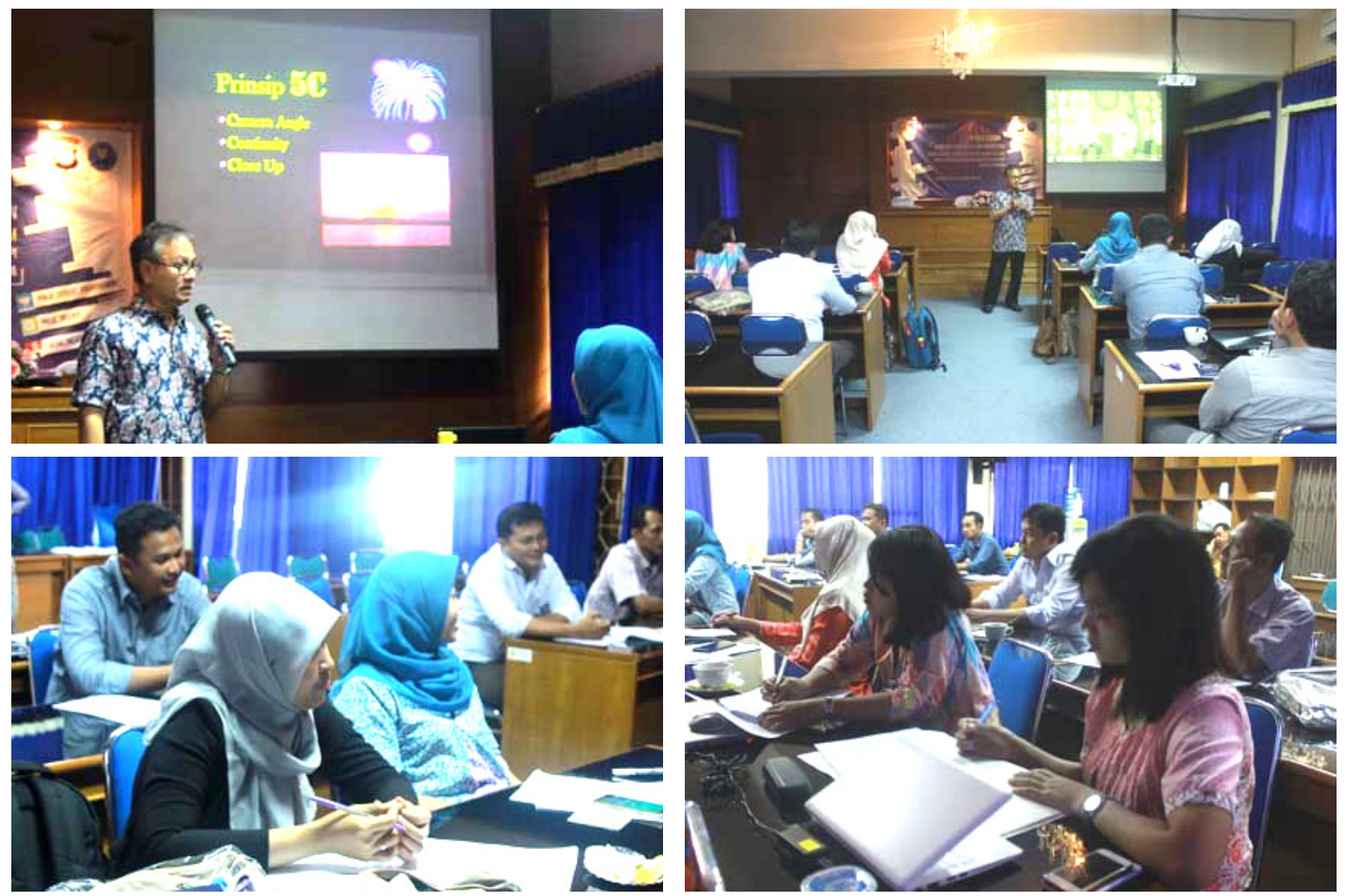

Gambar 1. Pelatihan penulisan naskah \& sinematografi luaran kegiatan yang berupa film pendek, Iklan Layanan Masyarakat (ILM), press release, portal web dan media sosial, serta terbentuknya jaringan kerjasama dengan media. Kegiatan ini dilakukan di BNNP DIY dan Ditresnarkoba POLDA DIY dari tanggal 29 Agustus sampai 2 September 2016.

\section{HASIL DAN PEMBAHASAN}

Kegiatan IbM Target dari pengabdian ini adalah peningkatan keterampilan peserta dalam memanfaatkan teknologi komunikasi untuk produksi pesan. Setelah kegiatan berakhir maka peserta menguasai keterampilan audio visual yang diharapkan meliputi:

1. Dapat merumuskan konsep yang akan disampaikan kepada khalayak

2. Dapat menulis skenario

3. Dapatpengambilan gambar (penggunaan kamera video)

4. Dapat melakukan editing

5. Dapat membuat backsound

6. Dapat menentukan jingle 
Fokus pelatihan yang pertama yaitu pada pelatihan pengolahan pesan untuk media audio visual. Pada pelatihan ini peserta dibekali kemampuan dalam menulis naskah iklan masyarakat dan sinematografi. Pemateri dalam pelatihan ini yaitu Drs. Tri Geovani dari dreamlight production. Sebuah Production House Lokal di Yogyakarta. pada materi penulisan naskah peserta diberikan basic bagaimana tahapan dalam membuat sebuah naskah iklan iklan, dimulai dari penemuan gagasan atau ide, riset dan observasi, hingga menuliskannya dalam sebuah konsep iklan. Sedangkan pada materi sinematografi, peserta diajarkan mengenal konsep 5C dalam sinematografi, yang merupakan dasar pengambilan gambar dari semua produk audio visual.

Untuk menunjang kemampuan dalam bidang audio visual, peserta dibekali kemampuan dalam melakukan editing video. Editing video merupakan sebuah proses akhir dari pembuatan produk audio visual, dimana gembar yang telah diambil disusun sedemikian rupa hingga memebentuk satu rangkaian pesan yang jelas.

Kemampuan yang tidak kalah penting setelah mengikuti program audio visual ini adalah melakukan kerja kelompok (teamwork). Dalam membuat film pendek ataupun Iklan Layanan Masyarakat perlu kekompakan kelompok. Karya ini tidak akan menghasilkan karya yang optimal jika dikerjakan individual (bahkan tidak mungkin dilakukan. Karya ini membutuhkan banyak keahlian. Dalam kegiatan ini peserta terbagi ke dalam keahlian masing-masing. Hasil kolaborasi karya tersebut telah menghasilkan film pendek dan Iklan Layanan Masyarakat (ILM).
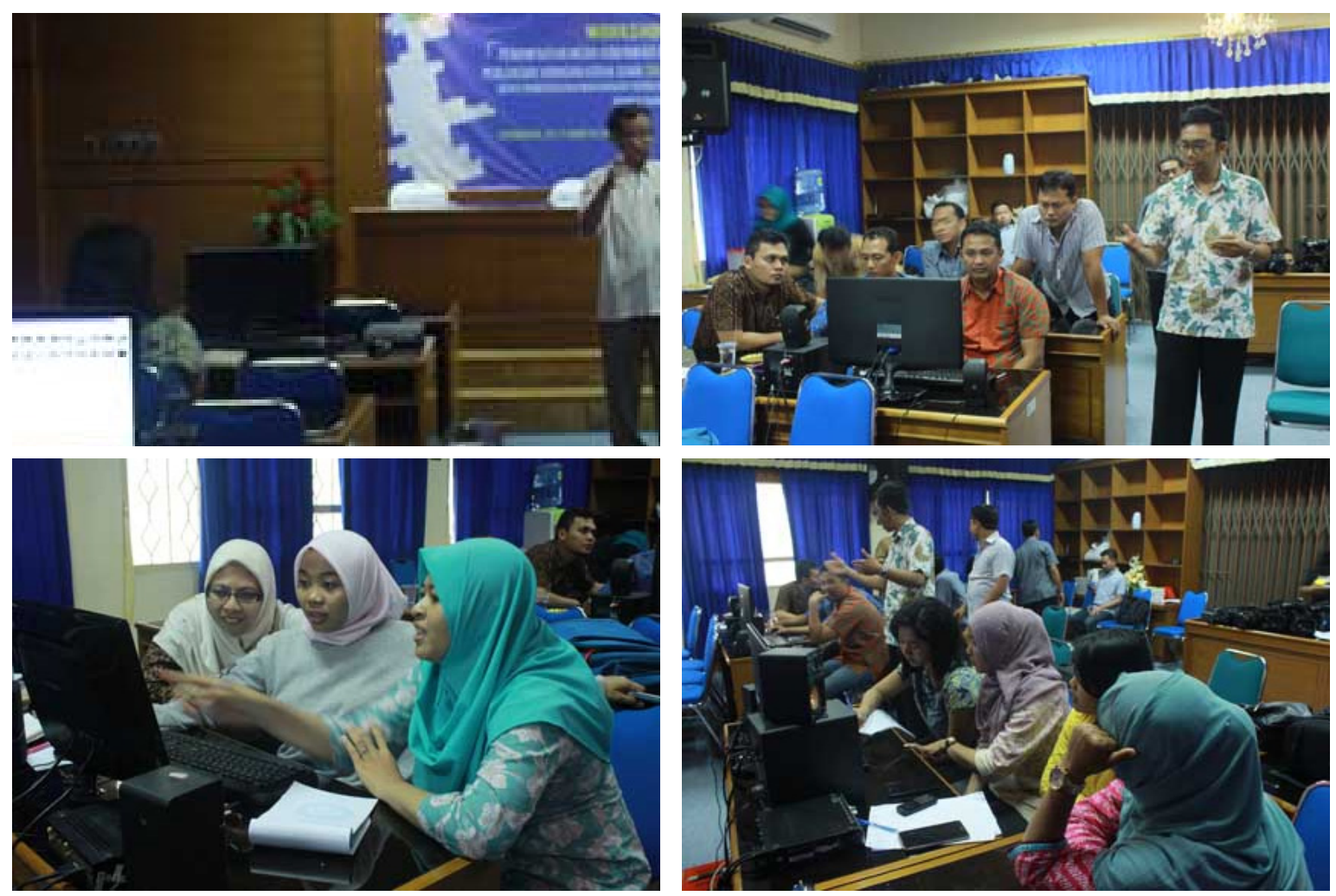

Gambar 2. Pelatihan Editing Video 

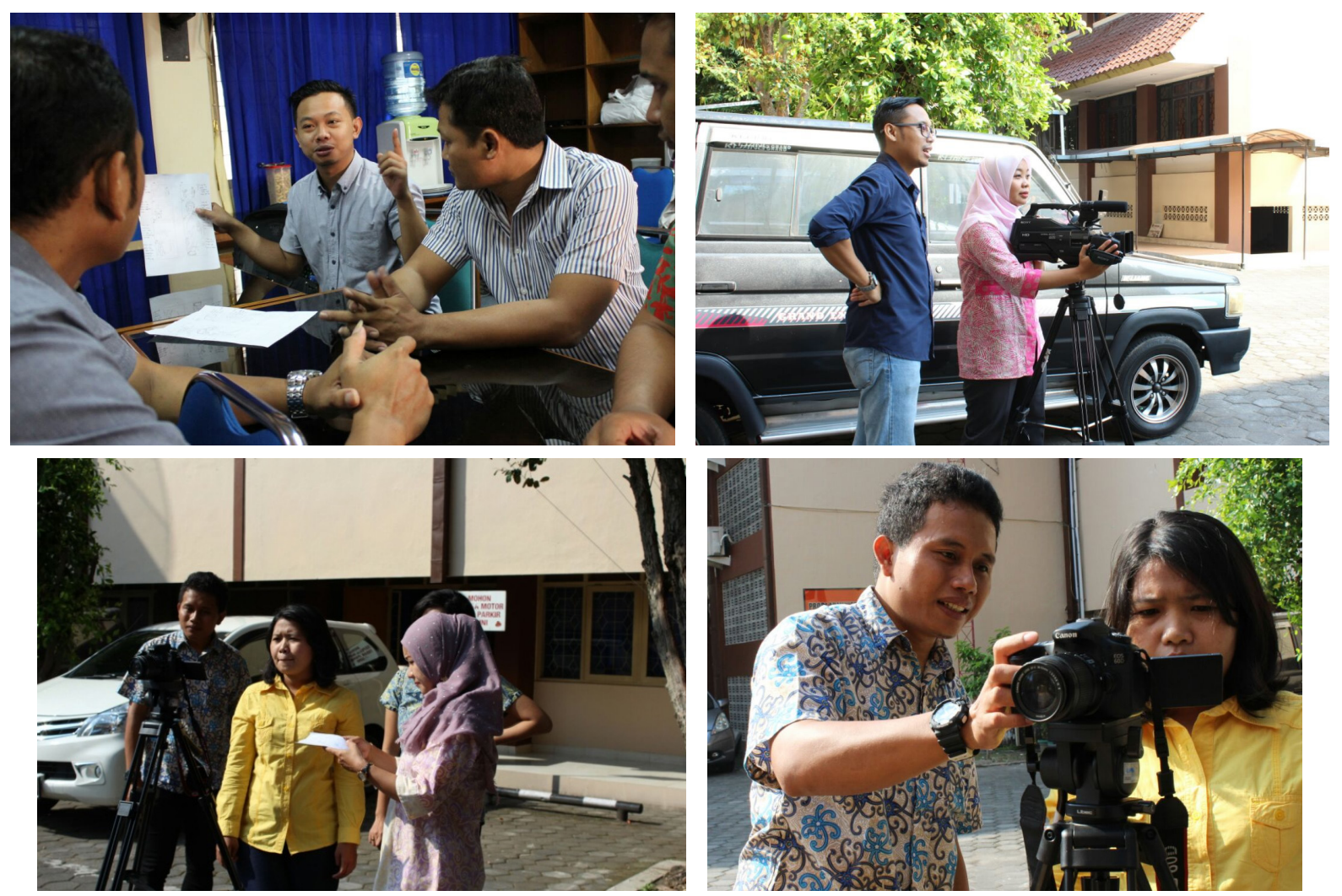

Gambar 3 . Penyusunan konsep dan pengambilan gambar

Keberhasilan sebuah produksi tidak terlepas dari manajemen produksi yang baik. Untuk dapat melakukan produksi dengan hasil yang maksimal, peserta harus mampu

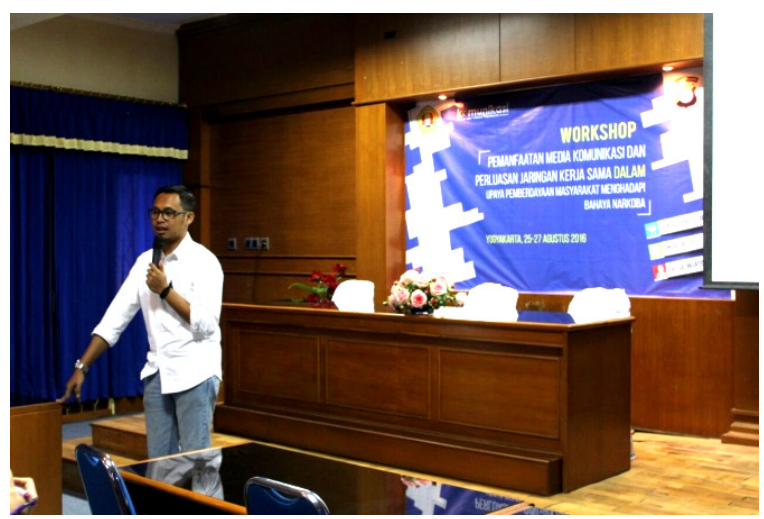

membuat perencanaan produksi yang baik. Untuk pemberian materi manajemen produksi sangatlah diperlukan dalam tata kelola produksi yang baik.



Gambar 4. Pelatihan manajemen produksi

Kemampuan lain lain yang dapat dilakukan oleh peserta adalah pembuatan press release. Peserta diajari berbagai kiat bekerja sama dengan wartawan, menulis press release, strategi memposisikan diri ketika berhadapan dengan wartawan. Hal penting yang ditekankan dalam workshop adalah supaya menghindari pemberian amplop kepada wartawan. Kejujuran menjadi modal utama supaya media mau memperhatikan lembaga. Hasil dari IbM ini peserta dapat menulis press release dan mengirimkannya ke surat kabar di Yogyakarta. 
Selain itu setelah mengikuti program ini para peserta diharapkan dapat mengelola media sosial khususnya konten yang disebarkan. Dari data yang ada baik BNNP DIY maupun Ditresnarkoba POLDA DIY memiliki akun media sosial, namun pengelolaanya kurang begitu efektif. IbM kali ini memberikan tips supaya media sosial yang dimiliki ke dua lembaga tersebut bisa terus aktif. Selain itu pengemasan konten dari media sosial tersebut yang disesuaikan denga karakter dan jenis media sosialnya. Hal ini penting karena setiap media sosial punya karakter sendiri. Pesan yang sama akan dikemas secara berbeda untuk setiap jenis media sosial. Penggunaan media sosial sendiri telah membentuk dan mendukung cara baru dalam berkomunikasi, berinteraksi dan berkolaborasi. Media sosial menawarkan cara yang lebih cepat dan tepat untuk berpartisipasi dalam pertukaran informasi melalui media online. Satu problem lain yang disampaikan peserta adalah kurangnya perhatian pimpinan terhadap managemen media sosial yang dimiliki. Untuk itu melalui kegiatan ini selain memberikan ketrampilan managemen media sosial, juga meyakinkan pimpinan akan pentingnya media sosial tersebut. Dengan pengertian dan pemahaman yang lengkap, pengaturan yang tepat, serta pengelolaan yang baik akan diperoleh manfaat dari penggunaan media sosial di instansi pemerintahan. Hasilnya sinergi antara pimpinan dan operator, media sosial yang dimiliki kedua instansi tersebut dapat kembali aktif menjadi media yang mampu menyampaikan pesan-pesan yang efektif yang dapat diterima oleh masyarakat.

Kemampun lain yang diberikan kepada peserta $\mathrm{IbM}$ adalah strategi memperluas jaringan dengan berbagai media. Hal ini dilakukan untuk bekerja sama dalam perolehan sharing time pada media baik untuk kegiatan penyuluhan maupun penayangan ILM. Upaya kerjasama yang dicoba pasca kegiatan ini adalah dengan menawarkan draft MOU antar media penyiaran ataupun media cetak dengan BNNP DIY dan Ditresnarkoba Polda DIY.

Tahapan selanjutnya setelah pelatihan yaitu pendampingan produksi ILM. Pada tahap ini masing-masing peserta dari POLDA dan BNN diharuskan membuat konsep ILM yang kemudian di produksi. Proses produksi melibatkan seluruh peserta yang didampingi fasilitator. Tempat pelaksanaan produksi dipilih yang sesuai dengan jalan cerita.
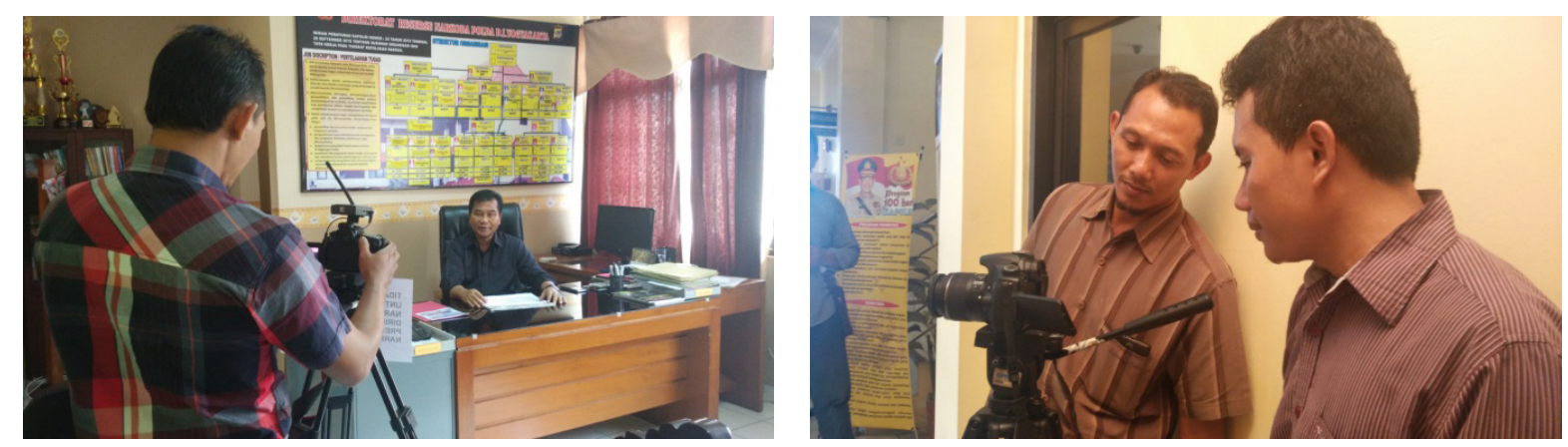

Gambar 5. Pendampingan produksi

Ditresnarkoba POLDA DIY mengangkat tema penggambaran kehidupan remaja yang hidupnya hancur karena narkoba. ILM yang dibuat polda menggunakan pendekan story dengan durasi 2,5 menit.

\section{Konsep iklan layanan masyarakat POLDA}

Tema : Bahaya Penyalahgunaan Narkoba

\section{Sinopsis}

Nadya berasal dari luar daerah Yogyakarta, karena prestasinya di sekolah menengah atas di daerahnya, Nadya mendapat bea siswa untuk berkesempatan melanjutkan pendidikan di salah satu universitas di Yogyakarta, sejak tahun 2015 Nadya kuliah dan bertempat tinggal kost di Yogyakarta, 
setelah satu setengah tahun tinggal di yogyakarta dan kurangnya pengawasan dari orang tuanya, nadya mulai mengenal dunia malam dan pergaulan bebas. Hingga suatu hari nadya mengenal dengan seorang lakilaki yang diakuinya sebagai pacarnya, lewat pacarnya tersebut nadya mulai coba-coba dengan narkoba.

Setelah kenal dengan narkoba tersebut akhirnya kuliahnya terbengkalai, Nadya sering tidak masuk kuliah dan selalu membohongi kedua orang tuanya untuk mengirim uang dengan alasan untuk biaya kuliah namun hanya untuk membeli narkoba.

Akhirnya dalam suatu operasi penggerebekan yang di lakukan petugas kepolisian, mengamankan beberapa orang yang sedang pesta narkoba dan salah satunya Nadya. Selanjutnya mereka di bawa ke kantor kepolisian untuk menjalani proses hukum lebih lanjut. Dari kejadian tersebut kedua orang tuanya baru mengetahui bahwa anaknya tersebut adalah seorang pecandu narkoba.

\section{Storyline}

\section{Scene 1}

NADYA lulus sekolah dengan predikat lulusan terbaik dan mendapat bea siswa untuk meneruskan pendidikan di Pergurian Tinggi di Yogyakarta.

(NADYA dengan gembira menerima ijasah, bea siswa dan piala penghargaan)

\section{Scene 2}

NADYA setiap hari rajin berangkat kuliah dan akhirnya kenal dengan seorang laki-laki dan menjadi pacarnya. (NADYA berangkat kuliah dan

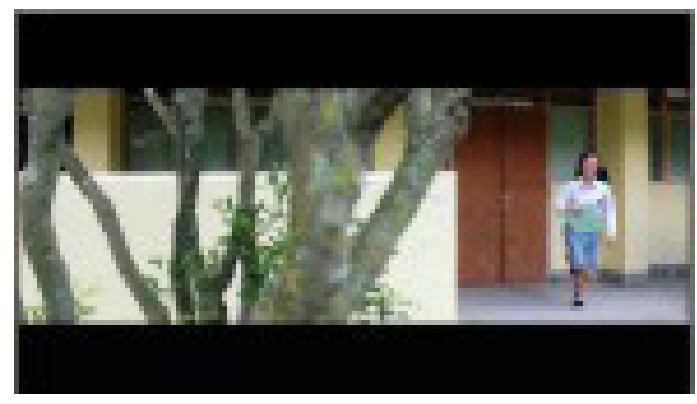

berkenalah dengan seorang laki-laki/ pacarnya)

\section{Scene 3}

Setiap hari NADYA di ajak keluar oleh pacarnya dan mulai mengenal dunia malam, pergaulan bebas dan diperkenalkan oleh pacarnya dengan narkoba.

(NADYA mulai mencoba narkoba di perkenalkan oleh pacarnya/ NADYA pakai narkoba di bantu oleh pacarnya)

Scene 4

NADYA mulai kecanduan narkoba dan sering meminta uang kepada orang tuanya dengan alasan biaya kuliah tetapi untuk membeli narkoba.

( NADYA kecanduan narkoba)

\section{Scene 5}

Nadya dan teman-temannya tertangkap dalam suatu pesta narkoba di kamar kostnya.

(NADYA bersama ke tiga temannya tertangkap saat pesta narkoba)

\section{Scene 6}

Masa depan NADYA hancur karena dikeluarkan dari tempat kuliahnya.

\section{Scene 7}

Himbauan dari Bpk DIRRESNARKOBA POLDA DIY KOMBES POL Drs. R ANDRIA MARTINUS, M.H. tentang bahaya penyalahgunaan narkoba.

(Kita bisa menggenggam dunia tanpa NARKOBA)

Berikut adalah beberapa potongan gambar dari hasil ILM yang di produksi POLDA

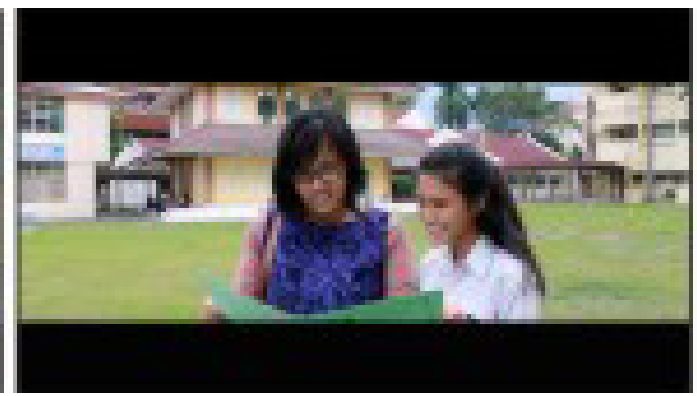



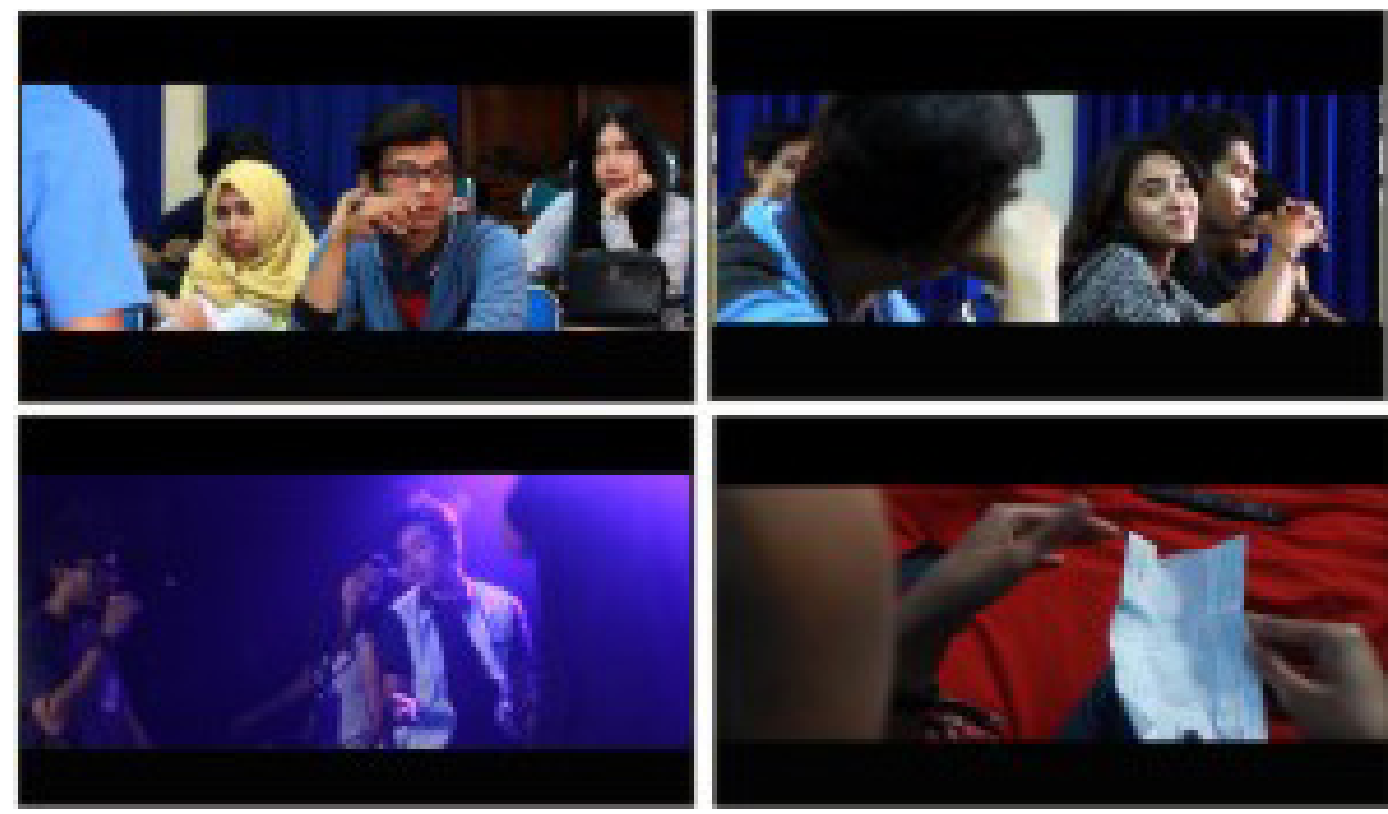

Sedangkan konsep yang diangkat menggunakan pendekatann stop motion. Menggambarkan dua remaja yang memilih hidup sehat dan yang satunya memilih menjadi pencandu narkoba. Perbandingan ini ditunjukan pada adegan yang memperlihatkan aktivitas 2 remaja yang yang sangat kontras. Remaja yang memilih hidup sehat menjali aktifitas kesehariannya dengan gembira, dan dia dapat memenuhi semua keinginannya menggunakan uang tabungan yang selalu disisihkan dari uang jajannya. Sedangkan pemuda yang satunya berkebalikan, awalnya dia menjalani hidup dengan gembira, kemudian mulai mencoba-coba narkoba, hingga mulai ketagihan. Uangnyapun habis hanya untuk membeli narkoba, hingga suatu ketiaka dia terpuruk akibat kelakuannya.

\section{Konsep ILM BNN}

Tema : Mana pilihan hidupmu?


\section{Storyline}

\section{Split Screne 1}

Pemuda A menjalani rutinitas hariannya, kuliah, nongkrong dan foya-foya. Menghamburkan uang. Mengkonsumsi narkoba. Uangnya semakin lama semakin habis, dan tubuhnya semakin melemah. Hingga tidak ada uang lagi dan sipemuda tumbang.

\section{Split Screne 2}

Pemuda B selalu tampil ceria dan gembira. Aktivitas kesehariannya diisi oleh hal-hal yang positif, berolah raga, bermain music, fotografi dan sebagainya. Dia juga selalu menyisihkan uangnya hingga dia bisa membeli apapun yang dia inginkan.

Berikut beberapa potongan gambar dari hasil ILM yang diproduksi BNN.

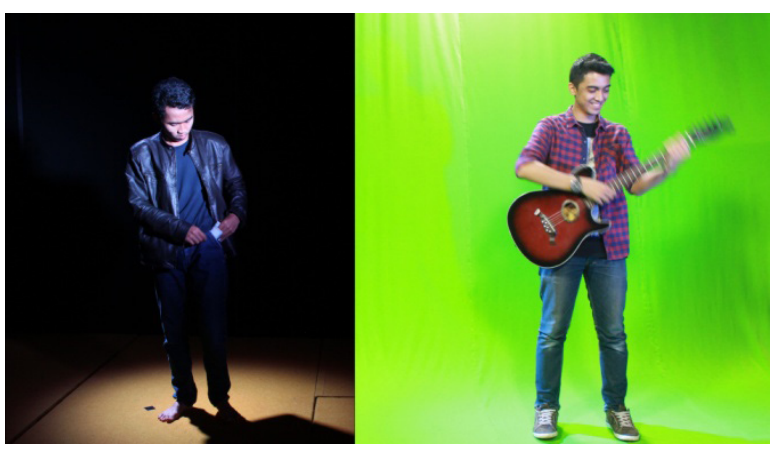



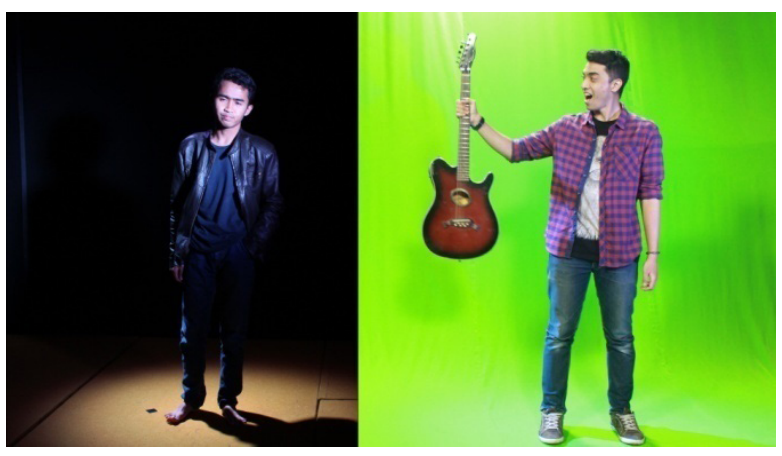

\section{KESIMPULAN}

Pelaksanaan kegiatan ini terbukti mampu memberikan wawasan baru terhadap personil BNNP DIY dan Ditresnarkoba POLDA DIY. Para personil yang memiliki latar belakang pendidikan yang berbeda-beda dari berbagai disiplin ilmu hampir sama sekali belum pernah terlibat dalam pengolahan media sebelumnya, khususnya dari Ditresnarkoba POLDA DIY.

Para personil dari masing-masing instansi setelah menempuh pelatihan selama 3 hari, telah mampu membuat naskah Iklan Layanan Masyarakat baik untuk media televise maupun radio. Selain itu juga telah mampu membuat video singkat yang

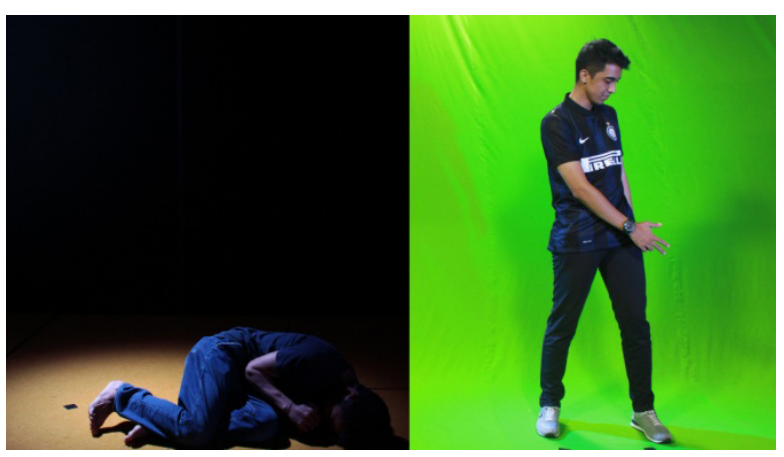

merupakan output dari materi sinematografi dan editing. Iklan Layanan Masyarakat untuk media radio juga telah bisa dihasilkan dari pelatihan ini, serta release kegiatan yang pernah dilakukan masing-masing instansi.

Setelah melalui berbagai rangkaian pelatihan dan produksi media, secara umum hasilnya sangat menggembirakan. Kompetensi yang dimiliki para personil semakin meningkat dan bisa dikatakan sudah mampu dan layak mengolah pesan media yang dapat ditayangkan di media massa maupun media sosial. Namun demikian, kompetensi ini harus terus dilatih guna semakin meningkatkan kualitas dari produk dalam hal ini pesan media yang dihasilkan.

\section{DAFTAR PUSTAKA}

Ari Prabawati, Theresia. 2009. Panduan Lengkap editing Video dengan Adobe Premiere Pro. Andi Publisher. Yogyakarta.

Effendy, Heru . 2010. Mari Membuat Film. Erlangga. Jakarta.

Fachrudin, Andi, 2012. Dasar-Dasar Produksi Televisi. Jakarta : Kencana Prenada Media Group.

Iriantara, Yosal. 2011. Media Relations. Simbiosa. Bandung

Morissan, MA., 2008. Manajemen Media Penyiaran Televisi dan Radio. Kencana Prenada Media Group. Jakarta.

Pujiyanto. 2013. Iklan Layanan Masyarakat. Penerbit Andi. Yogyakarta

Sudibyo, Agus. 2014. Strategi Media Relations. Gramedia. Jakarta

Wibowo, Fred. 2007. Teknik Produksi Program Televisi. Pinus Book Publisher. Yogyakarta

Widyatama, Rendra. 2011. Teknik menulis naskah iklan. Cakrawala. Jakarta 